\title{
Influence of different levels of dried citrus pulp on in vitro ruminal fermentation kinetics of total mixed ration in goat rumen inocula
}

\author{
J. Hernández ${ }^{1,4}$, R. Rojo ${ }^{1}$, A.Z.M. Salem ${ }^{2,6,7}$, F. Mirzaei ${ }^{3}$, \\ A. Gonzalez ${ }^{4}$, J.F. Vázquez ${ }^{1}$, O.D. Montañez ${ }^{5}$ and F.A. Lucero ${ }^{4}$ \\ ${ }^{1}$ Autonomous University of Mexico State, University Center of UAEM Temascaltepec, \\ Temascaltepec 51300, Mexico \\ ${ }^{2}$ Autonomous University of Mexico State, Department of Animal Nutrition, \\ Faculty of Veterinary Medicine and Zootechnic \\ Toluca 50000, Mexico State, Mexico \\ ${ }^{3}$ Deemed University, National Dairy Research Institute (N.D.R.I.), \\ Department of Livestock Production and Management, Karnal, India \\ ${ }^{4}$ Autonomous University of Tamaulipas, Faculty of Engineering and Science \\ Victoria City, Tamaulipas, Mexico \\ ${ }^{5}$ Guadalajara University, Department of Regional Development, University Center of the South, \\ Guzmán City, Mexico \\ ${ }^{6}$ Alexandria University, Faculty of Agriculture (El-Shatby), Egypt
}

(Received 14 April 2012; revised version 17 June 2012; accepted 14 September 2012)

\begin{abstract}
Inclusion of dried citrus pulp (DCP) at different levels: 0 (control), 10\% (DCP10), 20 (DCP20), and $30 \%$ (DCP30) of the total mixed ration (TMR) was evaluated by in vitro gas production (GP), and ruminal fermentation patterns, in a completely randomized design. Rumen fluid was collected before the morning meal from 8 gestating goats (Boer $\times$ Saanen, body weight $3 \pm 2.3 \mathrm{~kg}$ ). GP was recorded at 2, 4, 6, 8, 10, 12, 24, 48, 72, and $96 \mathrm{~h}$ of incubation. Ruminal fermentation parameters such as $96 \mathrm{~h}$ partitioning factor $\left(\mathrm{PF}_{96}\right)$, in vitro organic matter digestibility (IVOMD), metabolizable energy (ME), short-chain fatty acids (SCFA), and metabolizable energy (ME) were also estimated. Inclusion of DCP linearly increased $(\mathrm{P}<0.01)$ cumulative gas production at 24,48 , and $96 \mathrm{~h}$ after inoculation, as well as asymptotic gas production $(b)$. Rations at $30 \%$ and $10 \%$ DCP had the highest values of gas production, whereas control and $20 \%$ DCP presented the same values (quadratic effect $\mathrm{P}<0.01)$. Lag phase $(L)$ decreased linearly $(\mathrm{P}<0.001)$ with DCP addition. IVDMD and IVOMD
\end{abstract}

${ }^{7}$ Corresponding author: e-mail: asalem70@yahoo.com 
increased linearly $(\mathrm{P}<0.01)$ with the inclusion of DCP in rations. The ration at $30 \%$ DCP (DCP30) had the greatest value of ME and SCFA, but no differences were observed in the $\mathrm{PF}_{96}$ among treatments. The data suggest that the DCP30 ration had the best impact on rumen gas production and IVDMD, IVOMD, ME, and SCFA.

KEY WORDS: dried citrus pulp, gas production, in vitro fermentation, goat

\section{INTRODUCTION}

Conventional alternative feeds have been developed to meet the nutritional requirements of livestock during dry seasons. Food processing produces large amounts of by-products, but only a few of them have been successfully integrated as alternatives in livestock feeding because most of them are low in the major nutrients, and/or not balanced for them (Gado et al., 2011).

In Mexico, a large quantity of by-products from the citrus juice industry is obtained in the form of dehydrated citrus pulp ( $\mathrm{Ku}$ et al., 1993). Dried citrus pulp (DCP) is a widespread by-product used mainly in ruminant diets (Volanis et al., 2006). Ensiled and dried citrus pulp have been extensively studied on dairy cows (Belibasakis and Tsirgoyianni, 1996), fattening calves (Hadjipanayiotou and Louca, 1976), and lambs (Gado et al., 2011). Citrus pulp (DCP) modifies ruminal fermentation (Pinzón and Wing, 1976), improves fibre digestion (Gado et al., 2011), and increases microbial protein synthesis in dairy cows (Belibasakis and Tsirgoyianni, 1996; Gado et al., 2009), and sheep (Aregheore, 2000). Citrus pulp could be an alternative energy source replacing some grain in concentrate diets (Gado et al., 2011). It is noteworthy that the effects of including DCP in diets for goats on fermentation and nutrient metabolism have not yet been fully examined. Therefore, the objective of this study was to investigate the effect of different levels of DCP in diets on in vitro fermentation of gas production kinetics and energy utilization in goat rumen inocula.

\section{MATERIAL AND METHODS}

\section{Experimental diets}

Four total mixed rations (TMR) were formulated to include 4 levels of dried citrus pulp $(0 \%, 10 \%, 20 \%$, and $30 \%$ of the TMR). The rations met the nutritional requirements for non-lactating mature does in early gestation (40 $\mathrm{kg}$ body weight, feed consumption of $1.05 \mathrm{~kg}$ DM; NRC, 2007; Table 1). 
Table 1. Ingredients, chemical composition and secondary compounds ( $/ \mathrm{kg} \mathrm{DM})$ of the total mixed rations (TMR) with the different levels of dried citrus pulp (DCP)

\begin{tabular}{|c|c|c|c|c|c|}
\hline \multirow{2}{*}{ Indices } & \multicolumn{4}{|c|}{ TMR } & \multirow{2}{*}{$\begin{array}{l}\text { Dried citrus } \\
\text { pulp }\end{array}$} \\
\hline & Control & DCP10 & DCP20 & DCP30 & \\
\hline \multicolumn{6}{|l|}{ Ingredients } \\
\hline sorghum grain & 250 & 150 & 100 & 100 & \\
\hline soyabean meal & 90 & 90 & 90 & 90 & \\
\hline urea, $46 \% \mathrm{~N}$ & 10 & 10 & 10 & 10 & \\
\hline molasses & 20 & 20 & 20 & 20 & \\
\hline mineral premix ${ }^{\mathrm{b}}$ & 30 & 30 & 30 & 30 & \\
\hline Chenchus ciliaris & 600 & 600 & 550 & 450 & \\
\hline dried citrus pulp & 0 & 100 & 200 & 300 & \\
\hline \multicolumn{6}{|l|}{ Chemical composition } \\
\hline organic matter & 904 & 904 & 905 & 910 & 936 \\
\hline crude protein & 154 & 155 & 153 & 155 & 47 \\
\hline neutral detergent fibre (NDF) & 468 & 456 & 438 & 414 & 193 \\
\hline acid detergent fibre (ADF) & 243 & 239 & 236 & 226 & 126 \\
\hline \multicolumn{6}{|l|}{ Secondary compounds } \\
\hline total phenolics & 38.9 & 35.7 & 47.7 & 37.9 & 134.1 \\
\hline saponins & 40.0 & 48.5 & 39.7 & 53.6 & 45.9 \\
\hline aqueous fraction ${ }^{\mathrm{a}}$ & 88.0 & 108.5 & 122.4 & 139.2 & 187.5 \\
\hline
\end{tabular}

${ }^{a}$ aqueous fraction (lectins, polypeptides, starch; Cowan, 1999)

${ }^{\mathrm{b}}$ contained per kg of mineral premix: g/kg: Ca 19.60, S 22.10; mg/kg: Co 4, I 15.93, Se 15.49

\section{Preparation of diet extract to determine secondary metabolites}

Secondary metabolites were determined as outlined previously in Salem et al. (2011). Briefly, the experimental diets were ground in a Willey-mill to pass a $1 \mathrm{~mm}$ screen and immediately extracted at $1 \mathrm{~g} / 8 \mathrm{ml}$ of solvent mixture. The mixture of solvents contained $10 \mathrm{ml}$ methanol (99.8/100, analytical grade, Fermont $^{\circledR}$, Monterrey, Mexico), 10 ethanol ml (99/100, analytical grade, Fermont ${ }^{\mathbb{}}$, Monterrey, Mexico), and $80 \mathrm{ml}$ distilled water. Rations were individually soaked and incubated with the solvent mixture in the laboratory at $25-30^{\circ} \mathrm{C}$ for $48-72 \mathrm{~h}$ in closed flasks. After incubation, all flasks were incubated in a water bath at $39^{\circ} \mathrm{C}$ for one $\mathrm{h}$ and then immediately filtered; the filtrates were collected and stored at $4^{\circ} \mathrm{C}$ for further use.

\section{Proximate analysis and secondary metabolites}

Samples of each diet were analysed for DM, ash, CP $(\mathrm{N} \times 6.25)$, and ADF according to AOAC (1990). The NDF analyses were according to the Van Soest et al. (1991) procedure, using an ANKOM 200 Fibre Analyzer Unit (ANKOM Technology Corporation, Fairport, NY, USA). Total mixed rations were extracted using a mixture of ethanol, methanol and water (40:40:20) and secondary 
metabolites were determined using $10 \mathrm{ml}$ of different TMR. The extract was fractionated using ethyl acetate $\left(99.7 / 100\right.$, analytical grade, Fermont ${ }^{\mathbb{Q}}$, Monterrey, Mexico) to determine total phenolics by drying and quantifying the layer in the funnel. After total phenolics separation, n-butanol (99.9/100, analytical grade, Fermont $^{\circledR}$, Monterrey, Mexico) was added to fractionate the saponins (Makkar et al., 1998). The remaining solution was considered to be the aqueous fraction (lectins, polypeptides, starch; Cowan, 1999).

\section{Donor animal's inocula}

Rumen fluid was collected by a stomach tube before the morning meal from 8 gestating goats (Boer $\times$ Saanen, body weight $39 \pm 2.3 \mathrm{~kg}$ ). The animals had access to clean water and were fed twice daily at 07.00 and $16.00 \mathrm{~h}$ for 15 days before sampling. Ruminal fluid was obtained using a stomach tube from multiple sites in the rumen, strained through two layers of muslin and then kept for $30 \mathrm{~min}$ at $39^{\circ} \mathrm{C}$ under a continuous $\mathrm{CO}_{2}$ stream.

\section{Gas production assay}

The gas production assay was carried out according to Theodorou et al. (1994). A sample of $1 \mathrm{~g} \mathrm{DM}$ (each one of the TMR; Table 1) was weighed in triplicate into $160 \mathrm{ml}$ serum bottles. Anaerobic buffer solution $(90 \mathrm{ml}$, containing microand macroelements, a reducing agent, and a reduction indicator of resazurin) was added to the bottles containing $10 \mathrm{ml}$ of ruminal fluid. Negative controls (blank) containing buffered rumen fluid but no substrate were also included in triplicate for correction of gas produced from small particles present in the ruminal fluid. Cumulative gas production (m1/g DM) was recorded at 2, 4, 6, 8, 10, 12, 15, 19, $24,30,36,48,72$, and $96 \mathrm{~h}$ after incubation at $39^{\circ} \mathrm{C}$. The volume of gas produced after $24 \mathrm{~h}$ of incubation $\left(\mathrm{GP}_{24}\right)$ was used as an index of energy feed value of tree fodder samples (Menke and Steingass, 1988).

\section{In vitro degradability}

At the end of incubation ( $96 \mathrm{~h}$ ), the contents of each serum bottle were filtered through sintered glass crucibles (coarse porosity no. 1, 100- to $160 \mu \mathrm{m}$ pore size, Pyrex, Stone, UK) under a vacuum. Fermentation residues were dried at $105^{\circ} \mathrm{C}$ overnight and then incinerated in a muffle furnace at $550^{\circ} \mathrm{C}$ for $12 \mathrm{~h}$. Loss in weight after incineration was used as a measure of ash. The in vitro organic matter degradability (IVOMD) at $96 \mathrm{~h}$ of incubation was calculated as the difference between the OM content of the substrate and its undegradable OM. 


\section{Calculations}

The pressure generated by the gas accumulated in the upper part of the incubation bottles was measured through a pressure transducer connected to a digital reader. The equation previously obtained using regression analysis was as follows:

$$
Y=-0.807+6.86 X+0.083 X^{2}
$$

where: $\mathrm{Y}$ - volume (ml), X - pressure (psi); $\mathrm{R}^{2}=0.99$.

The gas production data ( $\mathrm{ml} / \mathrm{g} \mathrm{DM})$ were then fitted using the NLIN option of SAS (2002) to the model of France et al. (2000) as follows:

$$
A=b \times\left(1-\mathrm{e}^{-c(t-L)}\right)
$$

where: $A$ - volume of gas production at time $t ; b$ - asymptotic gas production $(\mathrm{ml} / \mathrm{g} \mathrm{DM}) ; c$ - rate of gas production (h), and $L(\mathrm{~h})$ - lag time.

Metabolizable energy (ME, MJ/kg DM) was estimated according to the procedure by Menke and Steingass (1988), by the following equation:

$$
\mathrm{ME}(\mathrm{MJ} / \mathrm{kg} \mathrm{DM})=2.20+0.136 \mathrm{GP}+0.057 \mathrm{CP}
$$

where: $\mathrm{GP}_{24}$ - $24 \mathrm{~h}$ gas volume and $\mathrm{CP}(\% \mathrm{DM})$ of the experimental diets.

Short-chain fatty acids (SCFA) were calculated according to the equation from Getachew et al. (2002):

$$
\operatorname{SCFA}(\mathrm{mmol} / 200 \mathrm{mg} \mathrm{DM})=0.0222 \mathrm{GP}-0.00425
$$

where: GP - $24 \mathrm{~h}$ net gas production ( $\mathrm{ml} / 200 \mathrm{mg} \mathrm{DM})$.

Partitioning factors (PF, used as a measure of fermentation efficiency) were calculated as the ratio of OM degradation to total gas production at $96 \mathrm{~h}$ (i.e., OM disappearance (IVOMD)/total gas production $\left(\mathrm{GP}_{96}\right)$; Blümmel et al., 1997).

\section{Statistical analysis}

Data for in vitro gas production, gas production parameters $(b, c$ and $L)$, in vitro degradability (IVDMD and IVOMD), ME, SCFA, and $\mathrm{PF}_{96}$ were analysed using the general linear model procedure (SAS, 2002) for a completely randomized design with four treatments of three repetitions; means were tested using the Tukey test (Steel and Torrie, 1980). Linear and quadratic contrasts of DCP level were performed. 


\section{RESULTS}

The effect of including different levels of DCP in TMR on in vitro ruminal fermentation parameters $(b, c$ and $L)$, IVDMD, IVOMD, ME, SCFA, and $\mathrm{PF}_{96}$ are shown in Table 2 and Figure 1. Inclusion of DCP linearly increased $(\mathrm{P}<0.01)$ cumulative gas production at 24,48 , and $96 \mathrm{~h}$ after inoculation.

Table 2. In vitro fermentation characteristics of total mixed rations (TMR) with the different levels of dried citrus pulp (DCP) in goat rumen inocula

\begin{tabular}{|c|c|c|c|c|c|c|c|}
\hline \multirow{2}{*}{ Parameter } & \multicolumn{4}{|c|}{ TMR } & \multirow{2}{*}{ SEM } & \multicolumn{2}{|c|}{ Effects, P } \\
\hline & Control & DCP10 & DCP20 & DCP30 & & linear & quadratic \\
\hline \multicolumn{8}{|l|}{ Gas } \\
\hline $\mathrm{GP}_{24}$ & $174.6^{\mathrm{b}}$ & $183.9^{b}$ & $194.4^{b}$ & $221.3^{\mathrm{a}}$ & 5.52 & $<0.001$ & 0.15 \\
\hline $\mathrm{GP}_{48}^{24}$ & $256.6^{\mathrm{b}}$ & $265.9^{\mathrm{b}}$ & $277.5^{\mathrm{ab}}$ & $307.3^{\mathrm{a}}$ & 7.90 & $<0.01$ & 0.230 \\
\hline $\mathrm{GP}_{96}^{40}$ & $291.6^{\mathrm{b}}$ & $303.9^{\mathrm{ab}}$ & $314.4^{\mathrm{ab}}$ & $341.3^{\mathrm{a}}$ & 9.72 & $<0.01$ & 0.47 \\
\hline
\end{tabular}

Gas production parameters

$\begin{array}{lccccccr}b & 295.9^{\mathrm{b}} & 309.2^{\mathrm{ab}} & 319.1^{\mathrm{ab}} & 344.7^{\mathrm{a}} & 10.11 & <0.01 & 0.56 \\ c & 0.047^{\mathrm{ab}} & 0.044^{\mathrm{b}} & 0.046^{\mathrm{ab}} & 0.049^{\mathrm{a}} & 0.0009 & 0.07 & <0.01 \\ L & 5.02^{\mathrm{a}} & 3.62^{\mathrm{b}} & 3.52^{\mathrm{b}} & 3.64^{\mathrm{b}} & 0.192 & <0.001 & 0.01 \\ \text { VOMD } & 722.0^{\mathrm{b}} & 747.0^{\mathrm{b}} & 761.0^{\mathrm{ab}} & 793.7^{\mathrm{a}} & 10.26 & <0.01 & 0.72 \\ \text { VDMD } & 639.3^{\mathrm{b}} & 664.0^{\mathrm{ab}} & 672.7^{\mathrm{ab}} & 708.7^{\mathrm{a}} & 12.16 & <0.01 & 0.65 \\ \text { ME } & 7.83^{\mathrm{b}} & 8.09^{\mathrm{b}} & 8.41^{\mathrm{ab}} & 8.98^{\mathrm{a}} & 0.151 & <0.001 & 0.33 \\ \mathrm{SCFA} & 0.77^{\mathrm{b}} & 0.81^{\mathrm{b}} & 0.86^{\mathrm{b}} & 0.98^{\mathrm{a}} & 0.0245 & <0.001 & 0.15 \\ \mathrm{PF}_{96} & 2.48 & 2.46 & 2.43 & 2.33 & 0.082 & 0.25 & 0.65\end{array}$

means in the same row with different superscripts differ $(\mathrm{P}<0.05)$. SEM - standard error of the means $(n=3)$. GP - gas production ( $\mathrm{ml} / \mathrm{g} \mathrm{DM}$ at 24,48 and $96 \mathrm{~h}) ; b$ - asymptotic gas production $(\mathrm{ml} / \mathrm{g} \mathrm{DM}) ; c$ - fractional rate of gas production $(/ \mathrm{h}) ; L$ - lag time (h); IVDMD - in vitro dry matter degradability (g/kg DM); IVOMD - in vitro organic matter degradability (g/kg DM); SCFA short-chain fatty acid concentration (mmol); ME - metabolizable energy content (MJ/kg DM); $\mathrm{PF}$ - partitioning factor; $\mathrm{OM}$ - disappearance/total gas production $\left(\mathrm{GP}_{96}\right)$

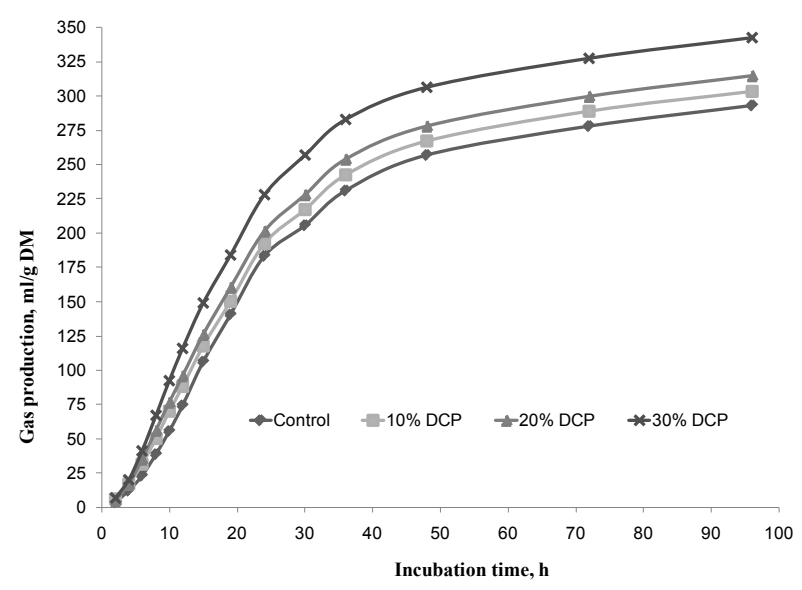

Figure 1. In vitro gas production profiles total mixed rations with the different levels of dried citrus pulp (DCP) in goat rumen inocula 
Dried citrus pulp increased $(\mathrm{P}<0.01)$ asymptotic gas production $(b)$ of TMR, while the fractional rate of gas production $(c)$ was different among treatments. Rations at $30 \%$ and $10 \%$ DCP had the highest values, whereas control and 20\% DCP presented the same values (quadratic effect $\mathrm{P}<0.01$ ). The lag phase $(L)$ decreased linearly $(\mathrm{P}<0.001)$ with DCP addition. The IVDMD and IVOMD increased linearly $(\mathrm{P}<0.01)$ with the inclusion of DCP in the diet. The ration at $30 \% \mathrm{DCP}$ had the greatest ME and SCFA values, but no differences were observed among treatments in the $\mathrm{PF}_{96}$.

\section{DISCUSSION}

Increase the DCP level in TMR (i.e., to DCP30) linearly increased gas production (Table 2; Figure 1), maybe because DCP contains a high amount of the neutral detergent soluble fibre fraction that includes pectin $(250 \mathrm{~g}$ pectin $/ \mathrm{kg}$ DM; Arthington et al., 2002)), soluble sugars (120 to $400 \mathrm{~g} / \mathrm{kg} \mathrm{DM})$, and less than $10 \mathrm{~g} \mathrm{starch} / \mathrm{kg}$ DM (Volanis et al., 2006). Pectin is the main carbohydrate in dried citrus pulp, and is quickly and extensively degraded by ruminal bacteria (Sunvold et al., 1995). Moreover, higher concentrations of fermentable carbohydrates in DCP increase gas production, degradable $\mathrm{N}$ compounds, and decrease gas production because of the binding of $\mathrm{CO}_{2}$ to ammonia (Krishnamoorthy et al., 1995). Substitution of feeds having high starch concentrations in TMR by others rich in rapidly fermentable carbohydrates, such as citrus pulp, avoids, at least in part, the negative effect on forage digestibility caused by high dietary starch levels (Barrios-Urdaneta et al., 2003).

The lower concentration of secondary compounds in DCP (Table 1) also improved gas production of the different TMR used, possibly due to the ability of rumen microorganisms to degrade them. These microorganisms can degrade alkaloids (Wachenheim et al., 1992), saponins (Hart et al., 2008) and phenolics (Varel et al., 1991) in plant extracts, however, and utilize them as an energy source. Administration of lower doses of leaf extracts rich in secondary compounds to ruminants as feed additives modified in vitro ruminal fermentation of high concentrate diets in lambs fed a daily dose of S. babylonica and L. leucocephala extract (Jiménez-Peralta et al., 2011), and improved in vivo digestibility and average daily gain of lambs (Salem et al., 2011).

Gas production reflects more on the digestible energy content of protein and fat (Aregheore, 2000) and it is generally a good indicator of digestibility, fermentability, and microbial protein production (Sommart et al., 2000). MacíasCruz et al. (2010) indicated that the DM, OM, and CP apparent digestibility and intake increased with the inclusion of citrus pulp at $75 \%$ of the diet DM. The improvements observed in the apparent digestibility of the diet may be due to 
the better nutrient profile and higher solubility of carbohydrates in the rumen, however, in the present study, IVDMD and IVOMD were improved with the increasing levels of DCP (linear effect $\mathrm{P}<0.01$; Table 2).

\section{CONCLUSIONS}

Inclusion of dried citrus pulp (DCP) at the level of $30 \%$ in goat rations positively influenced ruminal microbial fermentation and digestion of the carbohydrates of rapid soluble DCP, suggesting the possibility of using this citrus by-product as a potential alternative feed in goat nutrition.

\section{ACKNOWLEDGEMENTS}

Authors would like to thank to Consejo Nacional de Ciencia y Tecnología (CONACYT) for the grant received by Javier Hernández Meléndez. Authors wish to thanks Dr. Nicolas DiLorenzo (NFREC, University of Florida, USA) for his assistance and advices during revision of the manuscript.

\section{REFERENCES}

AOAC, 1990. Association of Official Analytical Chemists, Official Methods for Analysis. $15^{\text {th }}$ Edition. Arlington, VA

Aregheore E.M., 2000. Chemical composition and nutritive value of some tropical by-product feedstuffs for small ruminant-in vivo and in vitro digestibility. Anim. Feed Sci. Tech. 85, 99109

Arthington J.D., Kunkle W.E., Martin A.M., 2002. Citrus pulp for cattle the veterinary clinics. Food Anim. Pract. 18, 317-326

Barrios-Urdaneta A., Fondevila M., Castrillo C., 2003. Effect of supplementation with different proportions of barley grain or citrus pulp on the digestive utilization of ammonia-treated straw by sheep. Anim. Sci. 76, 309-317

Belibasakis N.E., Tsirgoyianni D., 1996. Effects of dried citrus pulp on milk composition and blood components in dairy cows. Anim. Feed Sci. Tech. 60, 87-92

Blümmel M., Steingss H., Becker K., 1997. The relationship between in vitro gas production, in vitro microbial biomass yield and $15 \mathrm{~N}$ incorporation and its implications for the prediction of voluntary feed intake of roughages. Brit. J. Nutr. 77, 911-921

Cowan M.M., 1999. Plant products as antimicrobial agents. Clin. Microbiol. Rev. 12, 564-582

France J., Dijkstra J., Dhanoa M.S., López S., Bannink A., 2000. Estimating the extent of degradation of ruminant feeds from a description of their gas production profiles observed in vitro: derivation of models and other mathematical considerations. Brit. J. Nutr. 83, 143-150

Gado H.M., Salem A.Z.M., Odongo N.E., Borhami B.E., 2011. Effect of exogenous enzymes ensiled with orange pulp on digestion, blood metabolites and growth performance in lambs. Anim. Feed Sci. Tech. 165, 131-136 
Gado H.M., Salem A.Z.M., Robinson P.H., Hassan M., 2009. Influence of exogenous enzymes on nutrient digestibility, extent of ruminal fermentation as well as milk production and composition in dairy cows. Anim. Feed Sci. Tech. 154, 36-46

Getachew G., Makkar H.P.S., Becker K., 2002. Tropical browses: contents of phenolics compounds, in vitro gas production and stoichiometric relationship between short chain fatty acid an in vitro gas production. J. Agr. Sci. 139, 341-352

Hadjipanayiotou M., Louca A., 1976. A note on the value of dried citrus pulp and grape marc for barley replacement in calf fattening diets. Anim. Prod. 23, 129-132

Hart K.J., Yanez-Ruiz D.R., Duval S.M., McEwan N.R., Newbold C.J., 2008. Plant extracts to manipulate rumen fermentation. Anim. Feed Sci. Tech. 147, 8-35

Jiménez-Peralta F.S., Salem A.Z.M., Mejia-Hernández P., González-Ronquillo M., Albarrán-Portillo B., Rojo-Rubio R., Tinoco-Jaramillo J.L., 2011. Influence of individual and mixed extracts of two tree species on in vitro gas production kinetics of high-concentrate diet fed to growing lambs. Livest. Sci. 136, 192-200

Krishnamoorthy U., Soller H., Steingas H., Menke K.H., 1995. Energy and protein evaluation of tropical feedstuffs for whole tract and ruminal digestion by chemical analyses and rumen inoculum studies in vitro. Anim. Feed Sci. Tech. 52, 177-188

Ku J.C., Nazar B.H., Alfaro M.A., 1993. Use of dried citrus pulp in ruminant nutrition (in Spanish). Biotam 5, 1-5

Macías-Cruz U., Quintero-Elisea J.A., Avendaño-Reyes L., Correa-Calderón A., Álvarez-Valenzuela F.D., Soto-Navarro S.A., Lucero-Magaña F.A.,González-Reyna A., 2010. Buffel grass (Cenchrus ciliaris L.) substitution for orange pulp on intake, digestibility, and performance of hair sheep lambs. Trop. Anim. Health Prod. 42, 223-232

Makkar H.P.S., Sen S., Blummel M., Becker K., 1998. Effects of fractions containing saponins from Yucca schidigera, Quillaja saponaria and Acacia auriculoformis on rumen fermentation. J. Agr. Food Chem. 46, 4324-4328

Menke K.H., Steingass H., 1988. Estimation of the energetic feed value obtained from chemical analysis and in vitro gas production using rumen fluid. Anim. Res. Dev. 28, 7-55

NRC, 2007. Nutrient Requirements of Small Ruminants: Sheep, Goats, Cervids, and New World Camelids. National Academic Press. Washington, DC

Pinzón F.J., Wing J.M., 1976. Effects of citrus pulp in high urea rations for steers. J. Dairy Sci. 59, $1100-1103$

Salem A.Z.M., Olivares M., López S., González-Ronquillo M., Rojo R., Camacho L.M., Cerrillo S.M.A., Mejia H.P., 2011. Effect of natural extracts of Salix babylonica and Leucaena leucocephala on nutrient digestibility and growth performance of lambs. Anim. Feed Sci. Tech. $170,27-34$

SAS, 2002. SAS User's Guide: Statistics. Ver 9.0. SAS Institute. Cary, NC

Sommart K., Parker D.S., Wanapat M., Rowlinson P., 2000. Fermentation characteristics and microbial protein synthesis in an in vitro system using cassava, rice straw and dried ruzi grass as substrates. Asian-Austr. J. Anim. Sci. 13, 1084-1093

Steel R.G.D., Torrie J.H., 1980. Principles and Procedures of Statistics. 2nd Edition. McGraw-Hill International. New York, NY

Sunvold G.D., Hussein H.S., Fahey Jr. G.C., Merchen N.R., Reinhart G.A., 1995. In vitro fermentation of cellulose, beet pulp, citrus pulp, and citrus pectin using fecal inoculum from cats, dogs, horses, humans, and pigs and ruminal fluid from cattle. J. Anim. Sci. 73, 3639-3648

Theodorou M.K., Williams B.A., Dhanoa M.S., McAllan A.B., France J., 1994. A simple gas production method using a pressure transducer to determine the fermentation kinetics of ruminant feeds. Anim. Feed Sci. Tech. 48, 185-197 
Van Soest P.J., Robertson J.B., Lewis B.A., 1991. Methods for dietary fiber, neutral detergent fiber, and non-starch carbohydrates in relation to animal nutrition. J. Dairy Sci. 74, 3583-3597

Varel V.H., Jung H.G., Krumholz L.R., 1991. Degradation of cellulose and forage fiber fractions by ruminal cellulolytic bacteria alone and in coculture with phenolic monomer-degrading bacteria. J. Anim. Sci. 69, 4993-5000

Volanis M., Zoiopoulos P., Panagou E., Tzerakis C., 2006. Utilization of an ensiled citrus pulp mixture in the feeding of lactating dairy ewes. Small Ruminant Res. 64, 190-195

Wachenheim D.E., Blythe L.L., Craig A.M., 1992. Characterization of rumen bacterial pyrrolizidine alkaloid biotransformation in ruminants of various species. Vet. Hum. Toxicol. 34, 513-517 